\title{
THE PECULIAR POSITION OF GERMANIC RUNES IN THE HISTORY OF SCRIPT
}

\author{
ADRIAN PORUCIUC \\ Alexandru Ioan Cuza University, Iaşi, Romania
}

\begin{abstract}
The present article is based on the material of a keynote presentation that was delivered at the International Conference From Runes to the New Media and Digital Books, which took place at Alexandru Ioan Cuza University of Iaşi on 30-31 May, 2019. In order to make that material more coherent, the author of that presentation will add supplementary clues and comments, all meant to sustain the idea that the Old Germanic runes although commonly considered to be just alphabetic signs - have peculiar features that resemble the ones of much earlier historical scripts, and even of prehistoric ones, such as the now much discussed Danube Script. The issues and illustrations of this paper may be of interest not only for linguistic and cultural studies, but also for the domain of European history.
\end{abstract}

Keywords: visual communication, Danube script, folklore, runes, divination, ideography, phonography

To begin with, I will observe that a most important sector of the domain one may designate as "history of visual communication" is occupied by the history of script. In regard to the latter, one problem is that many people of today's world (and especially of Europe) consider "script" to mean - first of all, or even exclusively - "alphabetic writing". Such a perspective is not applicable, however, to Egyptian hieroglyphs, or Mesopotamian cuneiforms, or Chinese logograms. Another problem is the ongoing debate on whether earliest forms of script were invented for practical uses, or for divination and magic. The latter possibility is sustained by a significant number of recent scholars - including Gimbutas, Haarmann, Merlini, Lazarovici and Winn. ${ }^{1}$

\footnotetext{
${ }^{1}$ See list of works cited.
} 
Throughout the last half-century, many specialists have analyzed and classified numberless archaeological finds that reveal systematic use of figurative and non-figurative signs in the area of the "Danube Civilization" (sixth-fourth millennia BCE), which is represented by sites such as Vinča (Serbia), Karanovo (Bulgaria) and Tărtăria (Romania). The conclusions of the specialists under discussion indicate that the sign system designated as "Danube Script" (DS) is about two millennia older than the ancient writing systems of Egypt and Mesopotamia. In such a context, it would seem to be out-of-place to compare the Germanic runic script - whose earliest manifestations are said to date from the second century CE - to the apparently primeval Danube Script, or to the ancient scripts of Egypt, Mesopotamia, the Indus Valley, China, or the Eastern Mediterranean. Nevertheless, as pointed out in more detail below, the rather peculiar features of the Germanic runes reflect, practically, all the stages of the history of writing: from pictograms to abstract-looking logograms, and finally to phonograms, that is, to alphabetic signs.

As an introductory illustrative example - which may reveal particular meanings of the terms sign and script - I will quote from Cântecul lui Mircea Ciobanul (The Song of Mircea the Shepherd), a Romanian medieval ballad minutely discussed in one of Petru Caraman's volumes on Romanian folklore. ${ }^{2}$ The ballad presents itself as a mixture of legend and history. In fact, the only elements that may be said to be historical proper are the medieval context represented by the Wallachian princely court and its boyars, as well as by the name and the nickname of Mircea Ciobanul, a real sixteenth-century ruler of Wallachia (Ţara Românească - "The Romanian Country"). The historical personage under discussion certainly was not a mere shepherd (cioban) before becoming a prince ${ }^{3}$ his nickname actually alludes to the fact that he became rich by selling sheep, mainly to the Turks of the Ottoman Empire. Nevertheless, according to the ballad - created and cherished by illiterate "bards" of southern Romania - Mircea was a "lost" son of a princely family, and he spent his childhood among shepherds. When he grew up, he became aware of his noble extraction, and he went to the princely court to demonstrate that he actually was the brother of the then ruler of the country (Negru Vodă). In the ballad, the angry domn asks his boyars to check whether any "princely signs" were "written" (that is, tattooed) on the claimant's body. After all those "signs" are found in place, Mircea also produces (as supplementary proof) a written document that attested to his noble birth (ristob 'charter' being a rather misshapen dialectal version of a Greek loan that is spelled hrisov in standard Romanian). The end of the ballad shows the two brothers happily reunited.

\footnotetext{
${ }^{2}$ Caraman's volume was posthumously published, in 1988.

${ }^{3}$ English prince is the usual translation of Romanian domn (from Latin dominus), which was the title of Romanian rulers during the Middle Ages.
} 
Here are the most significant fragments of the ballad under discussion (in the original, plus my translation):

Boierii mi-1 dezbrăca

Şi de semne mi-l căta.

Şi ce semne că-mi găsia?

Găsia-n pieptu-i soarele,

Lumina cu razele;

Găsia în spate luna...

Şi-n creştetul capului

Scrisu-i spicul grâului;

Şi mai jos, la subţioară,

Scrisă-mi-i o săbioară:

Semne bune de domnie...

Dar cel mic ciobănaş

Mâna-n glugă că-mi băga

Şi ristobul că-mi scotea...

(The boyars undressed him/ And searched him for signs./ And what signs did they find?/ They found the sun on his chest,/ With its light and rays;/ They found the moon on his back.../ And on top of his head/ An ear of corn was written;/ And lower, under his arm,/ A little sword was written:/ All good signs of princedom.../ But the little shepherd/ Put his hand into his hood/ And he took out his charter...)

I chose Mircea's ballad, as an illustrative example, neither for its literary value, nor for its drops of history, but rather for its peculiar use of terminology commonly associated with script. Most remarkable is that the anonymous illiterate Romanians who transmitted the song under discussion from generation to generation (before it was recorded, at the beginning of the twentieth century) ${ }^{4}$ used two Romanian terms inherited from Latin, namely the noun semn 'sign' (< Lat. signum) and the participle scris 'written' (from the verb a scrie < Lat. scribere). The two terms, however, did not refer to written letters proper, but to tattooed symbols that were obviously figurative, as they appeared to be representations of "things" charged with special symbolism. Anyway, it is obvious that those meaningful representations could be promptly "read" by the boyars whose appointment was to check the tattoos on Mircea's body. That he also had a properly written "birth certificate" on him appears to have been a fact of secondary importance.

\footnotetext{
4 The ballad was first published by C. N. Mateescu in 1909, as indicated by Caraman (194).
} 
I considered that the references to symbolic tattoos in Mircea's ballad ${ }^{5}$ could provide a good introduction to the realm of Germanic runes, which although they became known to the world especially as characters of an alphabetic system - preserved many features that clearly indicate pre-alphabetic origins. Most books on the runic script present it as an "invention" that was quite recent in comparison with other systems of alphabetic writings, such as the Semitic, Greek, Etruscan and Roman scripts. Even an author who was aware of the fact that the Germanic runes were "bearers of potential powers without being "letters" does not fail to mention the mainstream opinion that the runes were "invented by 150 CE." ${ }^{16}$ However, there are serious arguments ${ }^{7}$ that urge us to take into consideration what Elliott (1989: 84-85) has to say on the runic script as resulting from "a gradual amalgamation of the two distinct streams: the alphabetic script on the one hand, the symbolic content on the other."

It is in the same context where Elliott refers to the obvious connection between the shapes of certain prehistoric Scandinavian Bronze-Age and IronAge "rock-carvings" and the shapes of many alphabetic runes; and he also refers to the ancient Germanic practice of casting lots. In that respect, the abovementioned runologist mentions that there are references to the respective Germanic practice in Plutarch and in Julius Caesar, but that the "most explicit testimony" is to be found in Tacitus' Germania. Here is what Tacitus wrote about the kind of sortilege that was in use among Germanics of his own time, that is, towards the end of the first century CE:

For auspices and the casting of lots [auspicia sortesque] they have the highest regard. Their way of casting lots [sortium consuetudo] is one and the same: after cutting off a branch of a fruit-bearing tree [virgam frugiferae arbori], they slice it into strips [in surculos], on which they mark certain signs [notis], and they throw them, at random, on a white cloth; then, after praying to the gods [...], the priest of the community [sacerdos civitatis], if the ritual is public, or the father of the family [pater familiae], if it is private, picks up three of those [...] and interprets the signs scored on them. ${ }^{8}$

What we may be sure about is that the "notes" Tacitus refers to were not alphabetic letters (that is, they were not phonograms). The signs inscribed on the three "strips" that a first-century Germanic diviner was expected to pick at random, for one particular "reading", must have been logograms (implying one

\footnotetext{
${ }^{5}$ I made use of the same ballad as an illustrative example in a previous article (Poruciuc 2009), in which I discussed references to script to be found in the lyrics of archaic Romanian folk songs.

${ }^{6} \mathrm{Cf}$. Merlini, in the volume Lazarovici, Lazarovici and Merlini (332).

${ }^{7}$ Several of those arguments are presented in Poruciuc 2011.

${ }^{8}$ Cf. Tacitus, Germania, 10 - Mauerberger's edition (50-51) (transl. A.P.).
} 
sign=one word, as in the case of the Chinese characters); and the diviner had to find the right connectives, in order to formulate a coherent prediction based on each particular set of three words. However, it appears that not very long after Tacitus, certain Germanics who had come to know about phonographic systems, such as the one used by the Romans, strove to invent their own alphabetic script; and, in doing so, they must have resorted to some letters from foreign alphabets, but, more significantly, they also attached phonetic values to many of their own magic and divinatory signs. That process was, in several ways, different from the one represented by the Greeks' acquisition of a West Semitic alphabetic script.

The Greeks altered the shapes of Semitic letters, but they also adopted many of the original names of those letters, with slight modifications: thus, 'aleph and betth became alpha and beta, respectively (whereof the compound alphabet was concocted); also, gimel became gamma and däleth became delta. The big difference was that whereas on Semitic soil many such letter-names corresponded to native Semitic words that designated real things ('aleph meaning 'ox', bèth meaning 'house', gimel meaning 'camel', etc.), on Greek soil those Semitic terms came to function as just names of letters (besides which the Greeks used letter-names that simply rendered pronunciation, as in the cases of $p i$ and $p s i$, or they referred to features of the corresponding letters, as in the cases of o-micron and o-mega). Worth observing is also that, to an important extent, the Greeks followed the West Semitic system of acrophony, in keeping with which the phonetic value of each letter was indicated by the initial sound of the corresponding letter-name; thus beta stood for $/ \mathrm{b} /$, delta stood for $/ \mathrm{d} /$, etc. In the case of the runic script, the application of such a principle is fully visible in the alphabetic system that was to become known as fupark, a designation based on the first six letters of the script under discussion. ${ }^{9}$

Runic inscriptions have been found not only in European countries in which Germanic peoples are still at home, such as Denmark and Sweden, but also in regions (of today's countries, such as Romania and Ukraine) which were temporarily controlled by Germanic military elites, be they Visigoths, Ostrogoths, or East Scandinavian Vikings (Varangians). In course of time, varieties of the original runic script were locally devised, by modifying the early shapes of the runes, or by increasing their number (mainly by adding diacritics to the original forms, in order to indicate specific sounds, as in the case of certain Anglo-Saxon runes), or by reducing that number to a minimum (as in the case of the Scandinavian runic systems of later times).

\footnotetext{
${ }^{9}$ In the earliest arrangement of runes, the first one, *fehu, represented the sound /f/, the second one, *urus, represented /u/, and so on.
} 
The "classical" (earliest) version of the runic script, known as the Elder Fupark (EF), contained 24 runes, divided into three "blocks" of eight characters each. The EF system was in use approximately between the second century and the fifth CE. For the presentation below, I resorted mainly to Owen 1966 and Antonsen 2002 (with my transliteration):

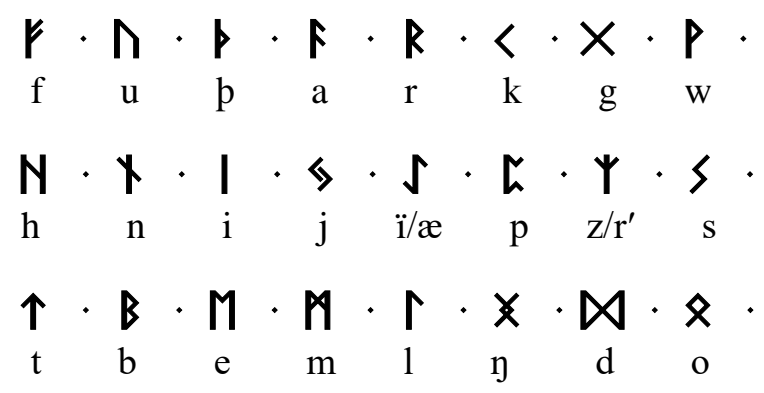

A major difference between the Germanic runic script and the one millennium older Greek script is that whereas the characters of the latter were designated by rather "technical" appellatives (which were letter-names only), the rune-names for which specialists commonly give reconstructed Proto-Germanic forms (see below) - constitute a true window to the ancient Germanic world. I will try to "open" that window, by turning the three EF blocks to vertical positions, in order to present the runes as attended by the Proto-Germanic rune-names as well as by corresponding phonetic values that were established acrophonically. (Two exceptions are: first, $\Psi *$ algiz, whose phonetic value, /z/ - which subsequently turned into a palatalized $/ \mathrm{r}^{\prime} /$ - is indicated by the final sound of its name; second, $X *$ inguz, which transcribes the sound $/ \mathrm{y} /$ in mid-word or final positions.)
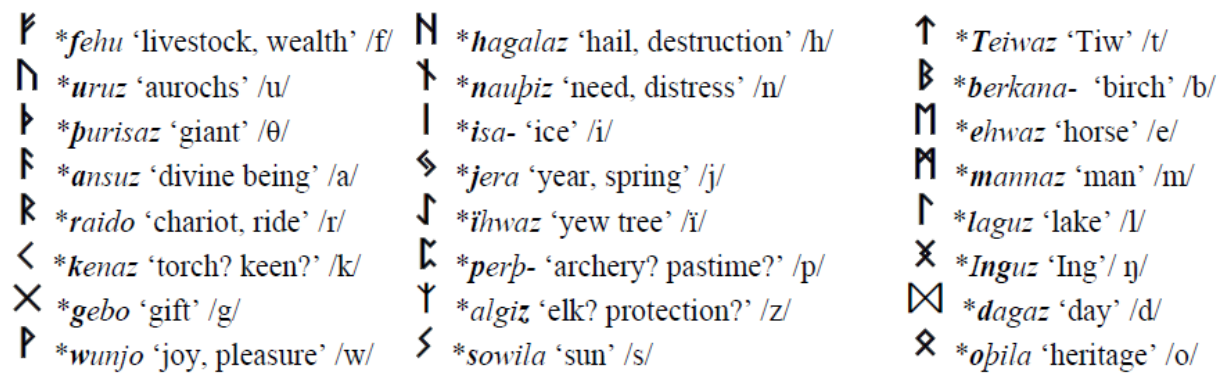

What we have above is a system of signs which, by their names, may be divided into categories that may be labeled as "environmental", "social", "ritualmythological", and even "psychological"; and all of them can be referred to 
distinctive features of the Old Germanic (Pre-Christian) world. For the discussion below, I made my own selection of illustrative examples. (I must add that I will avoid speculations regarding runes whose shapes or meanings remain controversial, or runes that were named too differently in various Old Germanic languages.)

As a matter of linguistic statistics I will observe that, according to my own counting, at least 13 of the $24 \mathrm{EF}$ rune-names reveal Proto-Indo-European (PIE) origins, as firmly established in etymological dictionaries (such as Köbler 1989, Vries 1961 and Pfeifer 2004). To begin with, the existence of a sun-rune (*sowila) is not surprising, since solar symbols may be considered as specific to PIE culture. Cognates of the rune-name *sowila are to be found, as names of the sun, not only in Germanic languages (cf. Gothic sauil and Old Norse sól), but also in diverse Indo-European languages such as Old Indic, which had süriyah 'sun', and Latin, which had sol 'sun' (cf. Ernout and Meillet 1985, s.v. sol). Also worth mentioning is the rune *berkana-, as Proto-Germanic name for birch, a word based on the PIE root *bherzg 'shining' (the reference being to the white bark of that symbolic tree of the Northern Hemisphere); the cognates of English birch include Germanic terms - such as Old High German biricha and Old Norse bjork - as well as non-Germanic ones, such as Old Indic bhürjah and Russian berëza, both designating the tree under discussion (cf. Pfeifer 2004, s.v. Birke).

The capital importance of livestock for Germanic communities (as well as for primeval PIE ones) is reflected in the name of the opening EF rune, *fehu (a perfect cognate of Latin pecu and Old Indic paśu), with a semantic evolution from 'livestock' (a meaning preserved by German Vieh) to 'wealth' and eventually 'money' (as still manifest in English fee, from Old English feoh). Emblematic PIE elements are also the ones reflected in the rune-names *ehwaz 'horse' (which can be referred not only to Old English eoh, but also to Lat. equus and Sanskrit açvah, as names of the horse) and *raido 'chariot' (cf. Old High German rad 'wheel', as well as Latin rota 'wheel' and Old Indic rathah 'war chariot'). Horses and horse-symbolism were of great significance in the traditional culture of ancient Indo-European peoples (from Indo-Iranians to Celts and Germanics); and, in that respect, we should observe that the domestication of horses and the use wheeled vehicles account for the amazing spreading of PIE speakers between the fifth millennium and the second BCE as indicated in Martinet 1986, Mallory 1989 and Gimbutas 1991. (And let me also observe that a semi-figurative horse-logogram was added to earlier stylized representations of bovines in the Bronze-Age Chinese script - cf. Mair 2003.)

Since the expected size of this article imposes limitations, I can only add that eight more rune-names have demonstrable PIE origins, and that outstanding among them is the one that represents the name of the Germanic war-god, *Tiwaz (still visible in English Tues-day), which is a cognate of Old Indic dyauh 
('daylight, divinity'), Latin deus and Greek Zeus. However, other rune-names that have something to do with Germanic divinities or mythical figures can hardly be interpreted as Indo-European (as indicated in the etymological dictionaries I made use of). That is, for instance, the case with *Inguz (which reproduces the name of a Germanic phallic god, recorded as Yngvi in Old Norse), as well as with *ansuz (cf. Old Norse áss 'god') and *burisaz (cf. Old English purs 'giant'). Also obscure are the rune-names *hagalaz 'hail' (which could be referred only to an etymologically obscure Greek word meaning 'pebble' - cf. Pfeifer 2004, s.v. Hagel), *lagus 'lake' (cf. Latin lacus, which has cognates only in a few European languages, so it cannot be safely considered to be Indo-European), and even *dagaz 'day' (which is also in need of a credible etymological explanation). These all may come from a Pre-Germanic "Old European" substratum. The same may be presumed about the last EF rune-name, *opila, which is as important for the ancient Germanic husbandry and mentality as *fehu, but, unlike the latter, it poses major etymological problems, regarding both form and sense (cf. Pfeifer 2004, s.v. Adel 'kin, nobility'). ${ }^{10}$ Last but not least, the rune-name *uruz (cf. Pokorny 2004, s.v. Auerochse) cannot be safely referred to any Indo-European relative. A possible cognate (itself of obscure origin) might be Latin urina, especially if we consider that the latter could also mean «liquide séminal», as indicated by Ernout and Meillet 1985 (s.v. urina). It is the same etymological dictionary that includes a brief article on one of the earliest words borrowed from Germanic into Latin, namely urus ('aurochs, wild bull'). That loanword was first used, in the first century BCE, by Julius Caesar, in a passage in which the great Roman general mentions wild beasts of Germania:

A third species is the aurochs [urus], an animal somewhat smaller than the elephant, with the appearance, colour, and shape of a bull. [...] The natives take great pains to trap them in pits, and then kill them. This arduous sport toughens the young men and keeps them in training; and those who kill the largest number exhibit the horns in public [...]. The horns are much larger than those of our oxen [...]. The Germans prize them greatly; they mount the rims with silver and use them as drinking cups at their grandest banquets. (De bello Gallico, 6, 28 - Handford edition 38)

What I should add here is that in early EF inscriptions (cf. Antonsen 2002: 315) the aurochs-rune had a symmetrical shape, like an inverted V, which I consider to be a stylized representation of a pair of sacral horns (cf. Poruciuc 2018).

\footnotetext{
${ }^{10}$ Noteworthy is the fact that the original semantic sphere of *opila (cf. Vries 1961, s.v. óðal 'heritage, property, homeland') is very similar to the one of Romanian moşie ('inherited communal land'), itself a word of substratal origin.
} 
Nowadays that representation, under the name of chevron, is known as an indicator of military ranks. In Baumgartner and Ménard's dictionary, French chevron, from Vulgar Latin *caprione, is presented as designation of both "hegoat" and "trestle" (cf. Romanian căprior 'roebuck, trestle'.) As for the real huge-horned aurochs (Bos primigenius), it appears that both Germanics and other Europeans took such "great pains" to kill it, that in became extinct towards the end of the Middle Ages. (However, as a proud Romanian, I cannot help mentioning that a heraldic aurochs-head - cap de bour - survived as capital item of Moldavia's coat of arms.)

As final illustrative examples, I will present three of the better-known EF inscriptions, the first of them being the one engraved on the much-discussed golden horn of Gallehus (Denmark), dating from ca. $400 \mathrm{CE}$. The precious object was discovered in 1734, and it subsequently vanished, fortunately not before the one-sentence inscription was transcribed. I will reproduce that inscription below (after Nielsen 2010: 97), with added transliteration and literal translation:

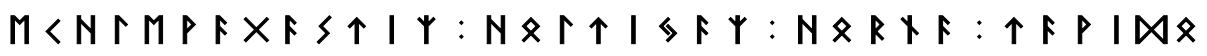 e k h l e wa gas t i z h o l t i ja z hor na t a wi do I, Hlewagastiz, (son) of Holt, (this) horn made}

The sentence - which (by its repeated /h/) sounds like a line in an Old Germanic alliterative poem - is opened by the archaic form of the Germanic first-person pronoun, ek (cf. Gothic ik, Old English ic, Old High German ih, as cognates of Latin ego). As for the rest of the lexical-grammatical material of the same sentence, it shows forms and inflexions of the ones that made specialists propound a designation such as "Northwest Germanic", for a language in which a clear differentiation between "Nordic" and "West Germanic" had not yet occurred (cf. Antonsen 2002: 33-35).

My second example is the Scandinavian inscription on the Möjbro Stone (Sweden), dating from ca. $500 \mathrm{CE}$. It appears to be a kind of explanatory text inscribed above the image of a horseman (whose name was presented as Frawaradar'). In a rather peculiar way, the inscription (with no marked separations between individual words) shows two lines running right-to-left and bottom-to-top, with a final letter suspended (for lack of room) above the end of the upper line. However, runologists managed to brush it up (cf. Elliott 1989: 32), so the text can be perceived as follows:

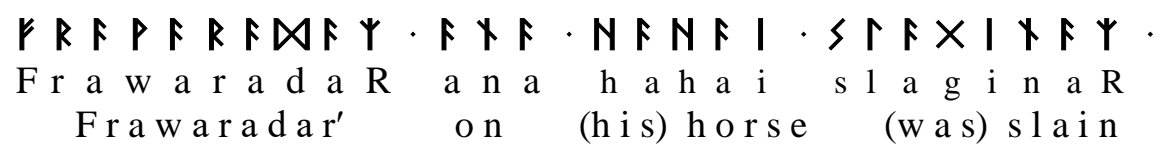


To note is that, as indicated by the capital R's used in the transliteration above, the phonetic value of the *algiz rune was different from the one assumed for the same rune in the Gallehus inscription: the shift from $/ \mathrm{z} /$ to a palatalized $/ \mathrm{r}^{\prime} /$ was among the changes that made Scandinavian Germanic appear as different from Northwest Germanic.

A third EF inscription - which was probably older than the two abovementioned ones - was engraved on a golden neck-ring included in the Visigothic hoard that was accidentally unearthed at Pietroasa (Romania) in 1837. The discovery was followed by a true thriller of repeated loss, destruction and recovery, as related in the three volumes of Odobescu's monograph (18891900). The precious items of the hoard appear to have been buried in the final quarter of the fourth century CE, possibly at a time when the Visigoths who lived (side by side with "free Dacians") in eastern territories of today's Romania prepared to face the invasion of the Huns. The Pietroasa inscription (as reproduced in several figures of Densusianu 1986) looks like this:

\section{$\times \Lambda \uparrow F Y$ XPINFIRFX.}

Proof of the respectable age of the Pietroasa inscription is the very fact that it appears as undivided into individual words; and it was the respective feature that represented a major difficulty for those who attempted to interpret that continuous row of EF runes. Also, the same hindrance provided a starting point for fanciful "theories" such as the one propounded by Densusianu, who saw "Pelasgian script" rather than Gothic runes on the Pietroasa ring (428), or the recent proposition of a "patriotic" Romanian blogger, who appears to be convinced that the inscription under discussion reflects "the Thracian ProtoRomanian language" (limbatracaprotoromana.blogspot.com). Serious specialists had no doubts that the signs cut on the Pietroasa ring are EF runes; however, even those specialists were not able to come to one and the same translation. Of the eight different interpretations mentioned on a Wikipedia page (en.wikipedia.org/wiki/Ring_of_Pietroassa), I am inclined to trust the one propounded by Krause (and accepted by Düwel), which is based on the following division of the inscription (under which I added corresponding Latin letters as well as what I consider to be a credible translation):

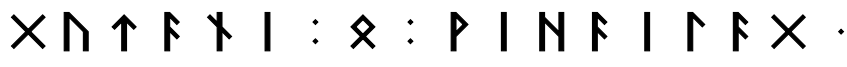

$$
\begin{aligned}
& \text { g u t a n i o w i h a i l a g } \\
& \text { (The) Goths' heritage sacrosanct }
\end{aligned}
$$

So, according to the Krause-Düwel vision, the ring of Pietroasa appears to contain the name of the Goths (in its genitive-plural form), followed by 
the *opila rune, used as a logogram, and by a contracted compound made of Gothic wih (cf. Wulfila's weih 'sacred' - see first element of German Weihnacht 'Christmas') and Gothic hailag, which obviously corresponds to German heilig and English holy. (Therefore, that compound looks like a loan-translation of Latin sacrosanctus.) As regards the "shorthand" (that is, logographic) use of the *opila rune in the middle of the Pietroasa inscription, it certainly was not a unique case. As a matter of personal experience, in scouring the abundant illustrative material included in Bosworth's Anglo-Saxon dictionary (ed. 1983), I became aware of the fact that - long after the adoption of the Latin script by the Anglo-Saxons - many runes were still used logographically. For instance, in his article on Old English feoh ('livestock, wealth, money'), Bosworth gives the example $\mathcal{F}_{\text {byp frofur fira gehwylcum (translated as "Money is a consolation to }}$ every man"); under daeg 'day', the corresponding rune appears as subject of the

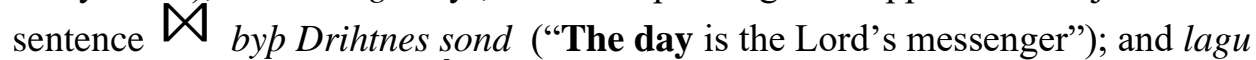
'lake' is illustrated by Swa $\uparrow$ toglidae ("So the lake glides to and fro").

In regard to my own attitude towards various views on the origin and evolution of the runic script, in the paragraphs above I avoided to take sides too openly. It is, however, rather obvious that I side with specialists (such as Owen, Elliott and Heizmann) who consider that most of the Germanic runes, by their shapes and/or names, reveal roots in ancient magic and in divinatory practices. I have sufficient reasons not to join the representatives of the opposite trend (such as Page, Antonsen and Looijenga), according to whom the runic script was simply a practical and commonly used instrument of communication (a vision that could actually be valid only with reference to the final Scandinavian stage of runic writing). As indicated by the introductory statements as well as by the illustrative part of this article, my view is that - in comparison with most other writing systems - the runic script preserved, up until its end, features that reflect all the main stages of the history of script. Along the same line, I consider that the study of runes may yield results that can prove to be significant not only for Germanic and Indo-European studies, but also for the history of Europe.

From a Romanian standpoint - and in the spirit of the logographic use of runes - I will finally state that the Pietroasa inscription stands for a very precious $\boldsymbol{x}$ that connects us to a segment of history during which the image of the noble beast called $\Lambda$ had to wait one more millennium before becoming the emblem of medieval Moldavia. As for the Pietroasa hoard, it was buried, most probably, in the period during which Wulfila - as first bishop of the Christianized "Danubian Goths" - decided to create a new alphabet, on a Greek basis, for his Gothic translation of the New Testament, which is now rightly considered to be the earliest comprehensive text written in a Germanic language. 


\section{References}

Antonsen, Elmer H. Runes and Germanic Linguistics. Berlin: Mouton de Gruyter, 2002. Print.

Askedal, John Ole et al., eds. Zentrale Probleme bei der Erforschung der älteren Runen. Frankfurt am Main: Peter Lang, 2010. Print.

Bosworth, Joseph. An Anglo-Saxon Dictionary. Ed. T. Northcote Toller. Oxford: Oxford University Press, 1983. Print.

Caraman, Petru. Studii de floclor, II. Ed. Viorica Săvulescu. Bucureşti: Minerva, 1988. Print.

Densusianu, Nicolae. Dacia preistorică. Eds. Victorela Neagoe and Manole Neagoe. Bucureşti: Meridiane, 1986. Print.

Düwel, Klaus. Runenkunde. Stuttgart: Metzler, 1983. Print.

Elliott, Ralph. Runes - An Introduction. New York: St. Martin's Press, 1989. Print.

Ernout, Alfred and Antoine Meillet. Dictionnaire étymologique de la langue latine. Paris: Klincksieck, 1985. Print.

Gimbutas, Marija. The Civilization of the Goddess. Ed. Joan Marler. San Francisco: Harper, 1991. Print.

Gimbutas, Marija. Die Ethnogenese der europäischen Indogermanen. Innsbruck: Institut für Sprachwissenschaft der Universität Innsbruck, 1992. Print.

Haarmann, Harald. Writing as Technology and Cultural Ecology - Explorations of the Human Mind at the Dawn of History. Frankfurt am Main: Peter Lang, 2011. Print.

Haarmann, Harald. Enigma civilizaţiei danubiene - Descoperirea celei mai vechi culturi de rang înalt din Europa. Transl., pref. and notes by Andrea Bargan and Norbert Poruciuc. Iaşi: Casa Editorială Demiurg, 2017. Print.

Handford, S. A., transl., ed. Caesar - The Conquest of Gaul. Baltimore: Penguin,1960. Print.

Heizmann, Wilhelm. „Zur Entstehung der Runenschrift”. Askedal et al. eds. 2010: 9-32. Print.

Köbler, Gerhard. Gotisches Wörterbuch. Leiden: Brill, 1989. Print.

Lazarovici, Gheorghe, Cornelia-Magda Lazarovici and Marco Merlini. Tărtăria and the Sacred Tablets. Cluj-Napoca: Editura Mega, 2011. Print

Looijenga, Tineke. Runes around the North Sea and on the Continent - AD 150-700. Groningen: SSG Uitgeverij, 1997. Print.

Mair, Victor H.. "The Horse in Late Prehistoric China: Wresting Culture and Control from the 'Barbarians'." Prehistoric Steppe Adaptation and the Horse. Eds. Marsha Levine, Colin Renfrew and Katie Boyle. Cambridge: McDonald Institute for Archaeological Research, 2003. 163-187.

Mallory, James P. In Search of the Indo-Europeans. Language, Archaeology and Myth. London: Thames \& Hudson, 1989. Print.

Martinet, André. Des steppes aux océans - L'indo-européen et les 'Indo-Européens'. Paris: Payot, 1986. Print.

Mauersberger, Arno, transl., ed. Tacitus - Germania. Zweisprachige Ausgabe, Lateinisch-Deutsch. Köln: Anaconda, 2009. Print. 
Nielsen, Hans Frede. "The Early Runic Language of Scandinavia: Proto-Norse or NorthWest Germanic?" Askedal et al. eds. 2010: 95-114. Print.

Odobesco [Odobescu], Alexandre. Le trésor de Pétrossa, I, II, III. Paris: Rotschild, 1889-1900. Print.

Owen, Francis. The Germanic People - Their Origin, Expansion and Culture. New Haven, Conn.: College \& University Press, 1966. Print.

Pfeifer, Wolfgang et al.. Etymologisches Wörterbuch des Deutschen. München: Deutscher Taschenbuch Verlag, 2004. Print.

Page, R. I. Runes. London: British Museum, 1987. Print.

Poruciuc, Adrian. "The Old Fairy, Pen in Hand, in the Netherworld." Signs of Civilization - Neolithic Symbol System of Southeast Europe. Eds. Joan Marler and Miriam Robbins Dexter. Sebastopol, CA: Institute of Archaeomythology, 2009. 213-219. Print.

Poruciuc, Adrian. "Old European Echoes in Germanic Runes?" Journal of Archaeomythology, 7 (2011): 65-72. Print.

Poruciuc, Adrian. "Symbolic Horns in Images and Words." Mankind Quarterly, 58. 3 (2018): 505-519. Print.

"Ring of Pietroassa." Wikipedia, The Free Encyclopedia. Wikipedia, The Free Encyclopedia, 30 Apr. 2020. Web. 3 May. 2020

Vries, Jan de. Altnordisches etymologisches Wörterbuch. Leiden: Brill, 1961. Print.

Văcaru, Marius. „Limba tracă protoromână.“ limbatracaprotoromana.blogspot.com. 1 Octombrie 2016. Web. 3 May 2020.

Winn, Shan M. M.. "The Danube (Old European) Script - Ritual use of signs in the Balkan-Danube Region c. 5200-3500 BC." Journal of Archaeomythology, 4. 1 (2008): 126-141. Print.

\section{BIONOTE}

Adrian Poruciuc began his career in 1971, at the Department of English of Universitatea "Alexandru Ioan Cuza" din Iaşi (UAIC). He got his full professorship in 2008. Before he retired from teaching, in 2013, he had taught ten different courses at UAIC. He presented at many congresses and conferences, in Romania and abroad. He also worked (half-post) for the Romanian Institute of Thracian Studies (Bucharest) and, subsequently, for the Institute of Archaeology (Iaşi). At present he still supervises PhD theses at the Faculty of History of the UAIC. Most of Professor Poruciuc's books and articles represent the fields of historical linguistics, Indo-European studies and archaeomythology. Some of his most significant volumes are the following: Prehistoric Roots of Romanian and Southeast European Traditions (Sebastopol, CA, 2010), A Concise History of the English Language (Iaşi, 2004), Limbă şi istorie engleză (Iaşi,1999), Archaeolinguistica (Bucureşti, 1995). He lectured at a number of foreign universities, including University of Chicago (as Fulbright Visiting Scholar, 1990-1992), Albert-Ludwigs-Universität Freiburg, Universidad de la Laguna, Nov Bălgarski Universitet. He became Fellow per la 
Letteratura, Compagnia di San Paolo - Bogliasco, Italy (2003) and Fellow of the Institute of Archaeomythology, Sebastopol, California (2005). He also belongs to the editorial boards of The Journal of Indo-European Studies and Mankind Quarterly.

E-mail: aporuciuc@yahoo.com 